\title{
Randomised controlled trials of physical activity promotion in free living populations: a review
}

\author{
Melvyn Hillsdon, Margaret Thorogood, Tim Anstiss, Jerry Morris
}

Occuptional Health

Department,

West London

Healthcare NHS

Trust,

Uxbridge Road,

Southall, Middlesex

UB1 3UE

M Hillsdon

Department of Public

Health and Policy,

London School of

Hygiene and Tropical

Medicine,

London WC1E 7HT

$M$ Thorogood

$\mathrm{J}$ Morris

Centre for Corporate

Health West London

Healthcare NHS

Trust,

Southall,

Middlesex UB1 3EU

T Anstiss

Correspondence to: M Hillsdon.

Accepted for publication April 1995

\begin{abstract}
Objectives - To review evidence on the effectiveness of trials of physical activity promotion in healthy, free living adults. To identify the more effective intervention programmes.

Methods - Computerised databases and references were searched. Experts were contacted and asked for information about existing work.

Inclusion criteria - Randomised controlled trials of healthy, free living adult subjects, where exercise behaviour was the dependent variable were included.

Conclusions - Ten trials were identified. The small number of trials limits the strength of any conclusions and highlights the need for more research. No UK based studies were found. Previously sedentary adults can increase activity levels and sustain them. Promotion of these changes requires personal instruction, continued support, and exercise of moderate intensity which does not depend on attendance at a facility. The exercise should be easily included into an existing lifestyle and should be enjoyable. Walking is the exercise most likely to fulfil these criteria.
\end{abstract}

(f Epidemiol Community Health 1995;49:448-453)

A recent meta-analysis of physical activity as a risk factor for coronary heart disease concluded that the relative risk in the least active compared with the most active was $1 \cdot 9 .^{1}$ Though this relative risk is similar to the risk of other factors, the prevalence of inadequate physical activity at around $70 \%{ }^{2}$ of the English population is greater than the $31 \%$ who smoke, $30 \%$ with a raised serum cholesterol concentration, and $15 \%$ who are hypertensive. ${ }^{3}$

There are randomised, controlled trials using exercise as an intervention in the management of health problems, notably hypertension, hyperlipidaemia, and overweight. These have demonstrated the importance of exercise in the management of disease. However, because their outcome variables are biological and physiological rather than exercise, they do not increase our knowledge of effective programmes to increase physical activity. They are therefore not included in this review.

We report a systematic review of randomised controlled trials of physical activity promotion in apparently healthy, free living adults (that is, people who were not receiving treatment for any illness and were not in an institution). The aim was to explore evidence of effective promotion of physical activity.

\section{Methods}

Searches were carried out using Medline, Excerpta Medica, SPORT (Data-Star), and Unicorn from 1966-93. Key words include "exercise", "community", "intervention", and "randomised controlled trial". Searches were also carried out on key authors identified from reviews. Only English language journals were searched. Two hundred and fifty abstracts were identified but only 18 described papers on randomised controlled trials. Additional searching was then carried out using the references from both existing reviews and the papers chosen from the abstracts. A further 37 papers were thus gathered. Each paper was read by two of us (MH and TA) and considered for inclusion.

The criteria for inclusion were as follows:

- A control group;

- Subjects were assigned to control or intervention by randomisation;

- Trials testing single factor interventions to increase activity;

- Interventions tested on apparently healthy, free living adults;

- Exercise behaviour was the dependent variable.

The quality of each paper was assessed using a three point scoring system. Each of three areas of potential bias in methodology were scored: (1) the quality of random allocation; (2) results analysed on intention to treat; (3) outcomes assessed without knowledge of assignment of subjects to groups by randomisation. Each of these areas then received a score of " 0 " or " 1 ", allowing for a maximum quality score of 3 or a minimum of 0 . 


\begin{tabular}{|c|c|c|c|c|c|c|}
\hline Study* & $\begin{array}{l}\text { Authors, year of publication, } \\
\text { stated objectives }\end{array}$ & $\begin{array}{l}\text { Length of } \\
\text { intervention }\end{array}$ & $\begin{array}{l}\text { Authors } \\
\text { description } \\
\text { of exercise }\end{array}$ & $\begin{array}{l}\text { Prescribed frequency, } \\
\text { intensity, and duration } \\
\text { of exercise }\end{array}$ & $\begin{array}{l}\text { Professional contact and } \\
\text { behavioural technique }\end{array}$ & Controls \\
\hline 1 & $\begin{array}{l}\text { Hoyt and Janis } 1975^{4} \\
\text { To test whether a relevant balance sheet } \\
\text { compared to an irrelevant balance sheet } \\
\text { would result in higher attendance at an } \\
\text { exercise group. }\end{array}$ & $7 \mathrm{wk}$ & Exercise class & Not stated. & $\begin{array}{l}\text { None after initial telephone } \\
\text { contact. Decisional balance } \\
\text { sheet. }\end{array}$ & No treatment \\
\hline 2 & $\begin{array}{l}\text { Reid and Morgan } 1979^{5} \\
\text { To assess the effectiveness of physician } \\
\text { prescribed exercise programme with health } \\
\text { education and self monitoring components. }\end{array}$ & $1 \mathrm{~h}$ & $\begin{array}{l}\text { Endurance } \\
\text { activity }\end{array}$ & $\begin{array}{l}\text { Advice about frequency, } \\
\text { intensity, duration given } \\
\text { but not described. }\end{array}$ & $\begin{array}{l}\text { Physician exam and personal } \\
\text { exercise advice. Health } \\
\text { educator presentation plus } \\
\text { video and self monitoring. } \\
1 / 12 \text { report on exercise } \\
\text { programme. }\end{array}$ & $\begin{array}{l}\text { Assessment } \\
\text { and written } \\
\text { exercise advice }\end{array}$ \\
\hline 3 & $\begin{array}{l}\text { King and Frederickson } 1984^{6} \\
\text { To study the effect of two low cost methods } \\
\text { of increasing the number of participant } \\
\text { controlled jogging episodes }\end{array}$ & $5 \mathrm{wk}$ & Jogging & $\begin{array}{l}4 \times \text { wk, individualised } \\
\text { time and distance goals. }\end{array}$ & $\begin{array}{l}\text { Team building exercises and } \\
\text { relapse prevention training for } \\
\text { different groups. }\end{array}$ & $\begin{array}{l}\text { Instructed to } \\
\text { jog alone }\end{array}$ \\
\hline 4 & $\begin{array}{l}\text { MacKeen et al } 1985^{7} \\
\text { To study the effects of an } 18 \text { month exercise } \\
\text { intervention on adherence. }\end{array}$ & $18 \mathrm{mth}$ & $\begin{array}{l}\text { Jogging, } \\
\text { swimming, } \\
\text { games }\end{array}$ & $\begin{array}{l}3 \times \text { wk minimum, } 35-75 \\
\text { min per session. }\end{array}$ & $\begin{array}{l}\text { Occasional risk factor meetings } \\
\text { with wives, no adherence } \\
\text { technique. }\end{array}$ & $\begin{array}{l}\text { Assessment } \\
\text { only }\end{array}$ \\
\hline 5 & $\begin{array}{l}\text { Kriksa et al } 1986^{8} \\
\text { To examine factors associated with exercise } \\
\text { compliance in post menopausal women }\end{array}$ & $2 y$ & Walking & $\begin{array}{l}3 \times \text { wk, brisk, } 3 \mathrm{ml} \text { per } \\
\text { session. }\end{array}$ & $\begin{array}{l}\text { Supervised walking sessions, } \\
\text { social gatherings, telephone } \\
\text { contact, self monitoring and } \\
\text { rewards. }\end{array}$ & $\begin{array}{l}\text { Assessment } \\
\text { only }\end{array}$ \\
\hline 6 & $\begin{array}{l}\text { King et al } 1988^{\circ} \\
\text { To evaluate strategies for enhancing the } \\
\text { adoption and maintenance of exercise } \\
\text { training by healthy middle aged men and } \\
\text { women }\end{array}$ & $6 \mathrm{mth}$ & $\begin{array}{l}\text { Walking and } \\
\text { jogging }\end{array}$ & $\begin{array}{l}4 \times \text { wk at } 65-77 \% \text { peak } \\
\text { heart rate for } 30 \mathrm{~min} \\
\text { per session. }\end{array}$ & $\begin{array}{l}\text { Telephone contact, self } \\
\text { monitoring and instructions on } \\
\text { relapse prevention and } \\
\text { adherence. }\end{array}$ & $\begin{array}{l}\text { No assessment } \\
\text { only controls }\end{array}$ \\
\hline 7 & $\begin{array}{l}\text { Noland } 1989^{10} \\
\text { To assess effects of behavioural techniques } \\
\text { on adherence to unsupervised exercise }\end{array}$ & $18 \mathrm{wk}$ & $\begin{array}{l}\text { Walking, } \\
\text { jogging and } \\
\text { swimming as } \\
\text { preferred }\end{array}$ & $\begin{array}{l}3 \times \text { wk at } 30-40 \% \text { or } \\
60-70 \% \mathrm{VO}_{2 \max } \text { for } \\
30 \mathrm{~min} .\end{array}$ & $\begin{array}{l}2 \text { Telephone } \\
\text { contacts + reminders if activity } \\
\text { logs late. Self monitoring and } \\
\text { rewards. }\end{array}$ & $\begin{array}{l}\text { Assessment }+ \\
\text { advice }+ \\
\text { telephone } \\
\text { support }\end{array}$ \\
\hline 8 & $\begin{array}{l}\text { King, Haskell et al } 1991^{11} \\
\text { To determine the effectiveness of group vs. } \\
\text { home based training of higher and lower } \\
\text { intensities }\end{array}$ & $1 \mathrm{y}$ & $\begin{array}{l}\text { Walking and } \\
\text { jogging }\end{array}$ & $\begin{array}{l}\text { Two groups } 3 \times \text { wk at } \\
73-88 \% \text { peak heart rate } \\
\text { for } 40 \text { min per session, } \\
\text { one group } 5 \times \text { wk at } \\
60-73 \% \text { peak heart rate } \\
\text { for } 30 \text { min each session. }\end{array}$ & $\begin{array}{l}\text { Supervised exercise for facility } \\
\text { based arm, telephone contact } \\
\text { for home based. Self } \\
\text { monitoring. }\end{array}$ & $\begin{array}{l}\text { Assessment } \\
\text { only }\end{array}$ \\
\hline 9 & $\begin{array}{l}\text { Suter and Marti } 1992^{12} \\
\text { To identify factors related to both exercise } \\
\text { adoption and long term adherence to a } \\
\text { home based jogging programme }\end{array}$ & $\begin{array}{l}4 \text { mth then } \\
\text { crossover }\end{array}$ & $\begin{array}{l}\text { Walking and } \\
\text { jogging }\end{array}$ & $\begin{array}{l}2-6 \times \text { wk at } 85 \% \text { of } \\
\text { heart rate at anaerobic } \\
\text { threshold for a total of } \\
120 \text { min per wk. }\end{array}$ & $\begin{array}{l}\text { Telephone contact and } \\
\text { personal feedback. Self } \\
\text { monitoring and individual } \\
\text { exercise prescription. }\end{array}$ & Waiting list \\
\hline 10 & $\begin{array}{l}\text { Marcus and Stanton } 1993^{13} \\
\text { To assess effectiveness of a relapse } \\
\text { prevention programme and reinforcement } \\
\text { programme in increasing exercise adherence } \\
\text { and short term maintenance }\end{array}$ & $18 \mathrm{wk}$ & $\begin{array}{l}\text { Exercise to } \\
\text { music class }\end{array}$ & $\begin{array}{l}3 \text { weekly classes } \\
\text { beginning at } 35 \text { min } \\
\text { and progressing to } 50 \\
\text { min duration. }\end{array}$ & $\begin{array}{l}\text { Weekly exercise class. Relapse } \\
\text { prevention training, } \\
\text { reinforcement and lottery. }\end{array}$ & $\begin{array}{l}\text { Attendance at } \\
\text { exercise group, } \\
\text { no behavioural } \\
\text { technique }\end{array}$ \\
\hline
\end{tabular}

\section{Results}

Ten papers met the inclusion criteria and are listed in table 1 . Only two of the papers were found from the computer searching. Nine trials were from the USA with one from Switzerland. None were from the UK. Most subjects were volunteers who responded to advertisements and were predominantly white, well educated, white collar workers. Overall, there was an even distribution between men and women with an age range of $24-72$ years (mean age approximately 49 years).

\section{INTERVENTIONS}

A summary of the interventions is shown in table 1 .

\section{Length of intervention}

Interventions ranged from one hour to two years and from a single educational session to regular contact with subjects.

\section{Professional contact}

In home based trials subjects usually received initial face to face instruction, which varied from simple exercise advice to the teaching of behavioural skills. Subjects attending facility based programmes and classes could have had more professional contact but no studies re- ported whether subjects did have such additional contact.

Subjects in home based interventions were usually telephoned after initial instruction. ${ }^{8911}$ This was sometimes for support and problem solving counselling. In other cases, however, subjects were telephoned only if they did not return self monitoring forms. No details of these calls are provided and we do not know if they were perceived as supportive.

\section{Behavioural techniques}

Self monitoring and relapse prevention training have been developed by researchers in addictive behaviours for increasing adherence to behaviour change. The two techniques were frequently used to change exercise behaviour.

\section{Exercise variables}

Most programmes were home based; only four trials used a designated facility. ${ }^{46713}$ Most of the trials involved jogging or walking, or sometimes the choice of either. Where these were not used, the activity was an exercise class or an unspecified aerobic activity. Subjects were asked to exercise between three and five times per week. The intensity of the exercise was often unspecified. When specified it was "moderate" except for jogging which was more vigorous, at approximately $80 \%$ of maximum heart rate. ${ }^{12}$ 
Table 2 Summary of results

\begin{tabular}{|c|c|c|c|c|c|c|}
\hline Study & $\begin{array}{l}\text { Quality } \\
\text { score } \\
(0-3)\end{array}$ & $\begin{array}{l}\text { No in } \\
\text { study }\end{array}$ & Subjects & $\begin{array}{l}\text { Post } \\
\text { intervention } \\
\text { follow up }\end{array}$ & $\begin{array}{l}\text { Actual frequency intensity and } \\
\text { duration of exercise intervention } \\
\text { group }\end{array}$ & Main outcomes $p<0.05$ \\
\hline 1 & 2 & 50 & Wives of graduate students & Nil & Mean frequency $=1 \cdot 7 / \mathrm{wk}$ & $\begin{array}{l}\text { Subjects in relevant balance sheet group attended } \\
\text { approximately twice as frequently as the irrelevant } \\
\text { balance sheet and control group. }\end{array}$ \\
\hline 2 & 1 & 124 & $\begin{array}{l}\text { Male firefighters aged } \\
24-56 \text { y }\end{array}$ & $3 \& 6 \mathrm{mth}$ & Not stated. & $\begin{array}{l}\text { No significant difference between groups at } 2 \mathrm{mth} \\
\text { follow up. }\end{array}$ \\
\hline 3 & 1 & 58 & $\begin{array}{l}18-20 \text { y old, previously } \\
\text { sedentary, female psychology } \\
\text { students }\end{array}$ & $2 \mathrm{mth}$ & $\begin{array}{l}\text { Mean frequency JAR and } \\
\mathrm{G}=2 \cdot 4 / \mathrm{wk} ; \mathrm{GR}=1 \cdot 4 / \mathrm{wk}\end{array}$ & $\begin{array}{l}83 \% \text { of jogging alone }+ \text { relapse subjects still } \\
\text { exercising at follow up compared with } 36 \% \text { of } \\
\text { control subjects. No significant difference between } \\
\text { groups on post study fitness levels. }\end{array}$ \\
\hline 4 & 1 & 315 & $\begin{array}{l}\text { Males aged } 53-72 \text { y with } \\
\text { one or no risk factors for } \\
\text { CHD }\end{array}$ & $12 \mathrm{y}$ & $\begin{array}{l}\text { Mean hours jogging/wk at year } \\
13=0.3 \mathrm{~h} .\end{array}$ & $\begin{array}{l}\text { No difference between exercise and control } \\
\text { conditions at follow up on jogging hours per } \\
\text { week. }\end{array}$ \\
\hline 5 & 2 & 229 & $\begin{array}{l}\text { Post menopausal women } \\
\text { aged } 50-65 \text { y }\end{array}$ & Annually & $\begin{array}{l}\text { Mean miles walking/wk }=8.4 \\
\text { Mean energy expenditure }= \\
1514 \mathrm{kcal} / \mathrm{wk} .\end{array}$ & $\begin{array}{l}\text { Self reported walking level significantly higher at } \\
\text { year } 1 \& 2 \text { compared with controls. }\end{array}$ \\
\hline 6 & 1 & 103 & $\begin{array}{l}52 \text { male and } 51 \text { female, } \\
\text { middle aged subjects }\end{array}$ & Nil & $\begin{array}{l}\text { Adoption } \text { arm }=\text { mean of } 3 \\
\text { sessions/wk for } 32 \text { min. } \\
\text { Maintenance arm }=\text { mean of } \\
2 \cdot 9 \text { sessions } / \text { wk for } 37 \text { min. }\end{array}$ & $\begin{array}{l}\text { Adoption arm }=\text { subjects receiving telephone } \\
\text { support showed significant increase in } \mathrm{VO}_{2 \max } \\
\text { Maintenance arm = daily self monitoring resulted } \\
\text { in greater exercise frequency than weekly self } \\
\text { monitoring. }\end{array}$ \\
\hline 7 & 1 & 77 & $\begin{array}{l}28 \text { men (mean age } 40 \text { ) and } \\
49 \text { women (mean age } 36 \text { ) }\end{array}$ & Nil & $\begin{array}{l}\text { Self monitoring group = mean } \\
\text { of } 2 \cdot 4 / \mathrm{wk} \text { for } 26 \text { mins. } \\
\text { Reinforcement group }=\text { mean } \\
\text { of } 2 \cdot 5 / \mathrm{wk} \text { for } 29 \text { mins. }\end{array}$ & $\begin{array}{l}\text { Increase in } \mathrm{VO}_{2 \max } \text { in all three conditions. } \\
\text { Behavioural interventions increased frequency of } \\
\text { exercise compared to controls. }\end{array}$ \\
\hline 8 & 2 & 357 & $\begin{array}{l}160 \text { women and } 197 \text { men } \\
\text { aged } 50-65 \mathrm{y} \text {. } \\
\text { Predominantly white and } \\
\text { well educated }\end{array}$ & On-going & $\begin{array}{l}\text { Mean frequency }= \\
\text { HIG } \sim 1 \cdot 2 / \text { wk } \\
\text { HIH } \sim 2 / \text { wk } \\
\text { LIH } \sim 3 / \text { wk }\end{array}$ & $\begin{array}{l}\text { Increase in } \mathrm{Vo}_{2 \max } \text { in all exercise groups. Higher } \\
\text { adherence in both home based conditions. No } \\
\text { changes in other CHD risk factors. }\end{array}$ \\
\hline 9 & 1 & 61 & $\begin{array}{l}\text { Middle or upper class, } \\
\text { middle aged, apparently } \\
\text { healthy, male bank workers }\end{array}$ & $4 \mathrm{mth}$ & Mean of $12.9 \mathrm{~km} / \mathrm{wk}$. & \multirow{2}{*}{$\begin{array}{l}\text { Only changes in vigour on psychometric test } \\
\text { significantly correlated with } 8 \text { mth activity levels. } \\
\text { No significant differences in lipids, blood } \\
\text { pressure, body composition or endurance capacity. } \\
\text { No significant difference in attendance at } 18 \mathrm{wk} \\
\text { or } 2 \text { mth follow up. }\end{array}$} \\
\hline 10 & 1 & 120 & $\begin{array}{l}\text { Previously sedentary, female } \\
\text { university employees with a } \\
\text { mean age of } 35 \text { y and mean } \\
\text { body mass index of } 25\end{array}$ & $2 \mathrm{mth}$ & $\begin{array}{l}\text { Percentage of classes attended } \\
\text { during the } 18 \mathrm{wk} \mathrm{RP}=51 \% \text {, } \\
\mathrm{R}=49 \% \text {. }\end{array}$ & \\
\hline
\end{tabular}

$\mathrm{JAR}=$ jogging alone + relapse prevention; $\mathrm{G}=$ group jogging; $\mathrm{GR}=$ group jogging + relapse prevention; HIG = high intensity group; HIH = high intensity home; $\mathrm{LIH}=$ low intensity home; $\mathrm{RP}=$ relapse prevention; $\mathrm{R}=$ reinforcement.

Where duration of prescribed exercise was specified it ranged between 15 and 75 minutes.

\section{Sustained improvement}

The development of coronary heart disease is a long process and evidence suggests that the health benefits of exercise cannot be saved up, so people must continue to exercise if they are to maintain their protection from coronary heart disease. Therefore, in this review more attention is paid to those trials with longer follow up periods.

\section{ASSESSING OUTCOMES}

Few studies included follow up of the subjects after the intervention. Of those which did, the average period was eight months with the exception of one trial which had a follow up period of 12 years. ${ }^{7}$ Definitions of good adherence ranged from exercising twice a week for 15 minutes to 7 miles of walking per week, or $100 \%$ of the prescribed sessions. Two trials measured $\mathrm{VO}_{2 \max }$ (the highest oxygen uptake attained during exercise involving large muscle groups). ${ }^{14}$

\section{OUTCOMES}

Table 2 shows the main outcomes.

\section{Professional contact}

Study 6 in table 1 varied the frequency of telephone contact and observed that subjects who received most contact exercised more fre- quently, for slightly longer, and achieved greater values than subjects receiving less contact and controls. ${ }^{9}$ In a later trial, ${ }^{11}$ the same team telephoned subjects performing home based exercise regularly, and compared adherence with that of subjects attending a facility based programme. After one year $79 \%$ and $75 \%$ of subjects in two home based groups were achieving over three quarters of prescribed exercise, compared to $53 \%$ of subjects randomised to a facility.

Study 5 in table 1, a trial of post menopausal women walking, in which professional contact was a major component, achieved high adherence at two years. ${ }^{8}$ Sixty one per cent of women in the intervention group were exercising at the level prescribed and four fifths were achieving $70 \%$ of the prescribed level, an increase in self reported walking over baseline of $79 \%$ compared with $16 \%$ in the control group.

\section{Self monitoring}

In trial 10 (table 1) subjects were randomly assigned to three groups, one of which was taught self monitoring techniques. ${ }^{13}$ There was a low adherence rate at six months and the authors concluded that "self monitoring did not produce a further increase in compliance". However, $55 \%$ of the self monitoring subjects did not complete their records. Those who did, achieved an adherence rate of $56 \%$ - nearly double that of the other treatment group. It is impossible to know whether subjects were reluctant to complete the record or were not undertaking the exercise. Trial 6 , took subjects 
from an earlier trial and randomised them to two 'maintenance' groups with different frequency of self monitoring. During the next six months, subjects completing daily self monitoring forms performed $35 \%$ more exercise sessions that subjects completing weekly forms.

\section{Relapse prevention}

Relapse prevention training was used in several trials but not described in detail. In trial 3, a trial of jogging alone or in a group and of jogging with and without relapse prevention training, $83 \%$ of subjects with relapse prevention in the two jogging alone arms were still exercising at three months compared with $36 \%$ of those without this training. ${ }^{6}$ In the two group jogging arms, however, there was no significant difference in the group with relapse prevention training, with $39 \%$ of subjects exercising in both groups.

Relapse prevention was compared with reinforcement strategies in trial 10, a study of women attending 18 weekly exercise classes. ${ }^{13}$ Subjects in the relapse prevention group received 18 weekly sessions on relapse prevention, including a planned 10 day break from exercise at nine weeks to demonstrate the possibility of lapsing and restarting exercise. Subjects in the reinforcement group received $\mathrm{T}$ shirts and other rewards for attendance, while controls subjects simply attended the exercise class. Attendance was not significantly higher in either intervention group compared with controls with the attrition rate (attendance at less than two thirds of exercise sessions) for all groups averaging $72 \%$ at 18 weeks.

\section{Location of exercise}

Trial 8 compared facility and home based programmes of different exercise intensities. ${ }^{11}$ The home based groups completed significantly more exercise sessions than the facility based group.

\section{Exercise frequency}

At the end of the trials those subjects still exercising were usually exercising around twice per week. One trial found that subjects prescribed three exercise sessions per week achieved higher adherence rates than those prescribed five at two year follow up. ${ }^{15}$

\section{Exercise intensity}

Few details of exercise intensity at follow up were reported. When they were, subjects exercised within the prescribed range (measured using telemetry heart rate monitors). Trial 8 , a study with both high and low intensity groups, found that the high intensity group preferred to train at the bottom of their target heart range while the low intensity group preferred to exercise at the top of their range. ${ }^{11}$ Thus, both groups moved towards moderate intensity exercise.
$\mathrm{VO}_{2 \max }$

In trial 6, subjects increased their $\mathrm{VO}_{2 \max }$ values by $7 \%$ to $8 \% .^{9}$ In trial 8 , subjects in all three intervention arms who performed greater than $75 \%$ of prescribed exercise sessions improved their $\mathrm{VO}_{2 \max }{ }^{11}$ In the two high intensity arms subjects improved by $7 \%$ and $9 \%$ respectively while in the low intensity arm they improved by $5 \%$. These physiologically significant changes were achieved by easily performed moderate intensity exercise.

\section{Discussion}

The wide variation in methodology and definitions of adherence in these few trials, make a formal meta-analysis unhelpful. The important public health question is whether attempts to modify exercise behaviour result in health gain in sufficient numbers of people to make these cost effective, and this review suggests that it is possible to increase the exercise levels of sedentary subjects. Trials that showed sustained high levels of participation (studies 5, 6 and 8) shared a number of common features. ${ }^{8911}$ These are:

- Home based programmes;

- Unsupervised, informal exercise;

- Frequent professional contact;

- Walking as the promoted exercise;

- Moderate intensity exercise.

Home based interventions were more successful than facility based programmes. One study (number 7) compared facility and home based exercise; the home based groups achieved significantly more exercise sessions. ${ }^{10}$ Another home based study (number 6 ) showed a positive relationship between the convenience of exercise and its adoption and maintenance, and this may explain why home based exercise seems preferable. ${ }^{9}$

Subjects who exercised alone completed more exercise sessions that those who exercised in groups. In a short jogging trial (number 3 table 1), subjects assigned to jogging alone with relapse prevention training performed over double the exercise of subjects who exercised as a group and were taught cohesiveness skills. ${ }^{7}$ The inconvenience of meeting at a specific time and place may reduce adherence to group based programmes.

High participation (studies 5, 6, 8) was also associated with frequent professional contact. $^{8911}$ Contact was usually made by telephone or occasionally by home visits. The amount of contact was not great. In one trial (number 6) subjects received less than $60 \mathrm{~min}$ utes of total telephone contact over 6 months. ${ }^{9}$ In another study (number 8 ) the authors reported an average of 15 telephone contacts of approximately three minutes over one year. ${ }^{11}$ The two home based arms which received telephone support performed significantly more exercise than the group based arm which did not.

The interaction between professional and client may be of greater importance than any behavioural technique. Addictive behaviour re- 
searchers have found that the way in which a therapist interacts with a client is a better predictor of treatment outcome than either the client characteristics or the therapist's theoretical orientation. ${ }^{16} \mathrm{~A}$ review of therapist effectiveness with substance use disorders concluded that good interpersonal skills of the therapists was associated with high effectiveness. ${ }^{17}$

Three successful trials used walking, which is already a popular form of exercise $e^{910}$ and does not require special equipment, a formal facility, or fellow participants. The promotion of exercise which is popular and can be incorporated into existing lifestyles may be more successful. Walking is normally a moderate intensity activity, and moderate intensity is associated with higher participation. Even subjects randomised to high and low intensity exercise may prefer moderate intensity. In one trial, subjects assigned to high intensity exercise, exercised at a mean rate of perceived exertion (RPE - a validated, subjective rating of exercise intensity) of $13,{ }^{18}$ whereas those assigned to low intensity exercised at a mean RPE of 11.7 (study 8 ), both moderate intensity levels.

A lesser frequency of prescribed exercise was associated with better maintenance. In study 3, subjects were prescribed four sessions per week but at one year subjects were averaging just over two sessions per week. ${ }^{7}$ In another trial, study 8 , subjects were assigned to either five, 30 minute or three, 40 minute sessions per week. The proportion achieving over $75 \%$ of prescribed sessions did not differ at one year, but at two years the three sessions per week subjects maintained a higher percentage. ${ }^{15}$

These trials indicate that it is possible to increase physical activity levels in free living individuals, but that improvements in physical fitness (measured as $\mathrm{VO}_{2 \max }$ ) are smaller than those found in laboratory studies.

The subjects in nine studies were volunteers who were considering increasing, or had decided to increase, their physical activity. In the one study that recruited by random digit dialling, 20418 numbers were dialled of which only $9 \%$ yielded subjects for randomisation, mainly due to the exclusion criteria. Of those eligible, only $27 \%$ were randomised, suggesting considerable self selection. ${ }^{19}$ While some studies have been successful they tell us nothing about promoting physical activity in people who would not have accepted an offer of participation in an exercise programme.

The four trials which continued for at least 6 months $(4,5,6,8)$ provide the basis for most of our conclusions. Subjects were all over 47 years of age, well educated, and white. Whether these results can be generalised to other populations, including those in the $\mathrm{UK}$, is not known.

Some of the 55 studies identified initially but not included because of methodological problems, involved techniques which might prove useful and should be evaluated. These included concepts of self efficacy, barriers to change, support and reinforcement, ${ }^{20}$ as well as a person's "stage of change" with regard to physical activity. ${ }^{2122} \mathrm{~A}$ further important question is whether subjects prescribed exercise as a treatment for a diagnosed condition are more likely to maintain it. That is, how important is the presence of ill health to compliance with prescribed exercise.

\section{FUTURE RESEARCH}

Further experimental research is urgently needed, particularly in three areas:

- Groups other than middle aged, middle class white people, looking at those at highest risk from coronary disease who might have the greatest capacity to gain from increased activity, particularly the elderly.

- Exploring the factors that might affect both initial uptake of the activity and subsequent adherence to a new activity level in subjects resident in the $\mathrm{UK}$.

- Exercise prescription to treat specific conditions.

\section{Conclusion}

It is possible to increase activity and maintain the increase at sufficient frequency and intensity for long term health gain. This is best achieved when exercise is home based, of moderate intensity, can be performed alone or with others, is enjoyable, convenient, and can be completed in three sessions per week. Walking will satisfy all of these criteria. Self monitoring and relapse prevention training may improve early adherence, and continuing support and reinforcement may improve long term adherence. An initial brief instructional session followed by short but frequent telephone support may be most effective. These interventions are low cost and easy to administer compared with facility based group exercise interventions where the barriers and costs associated with attendance may lead to high drop out rates.

These findings do not support the increasingly popular prescription for exercise schemes. A high proportion of these schemes involve general practitioners referring their patients to a leisure centre or similar facility, but we have found no evidence to support the efficacy of facility based interventions. These interventions are unlikely to be the most effective way of increasing population activity levels. Less than $1 \%$ of a practice list are referred into such schemes. ${ }^{23}$ Although they attract publicity, organisations would be wise not to rush into prescription for exercise schemes until evidence is available to support their efficacy. Financial assistance for this work was provided by the Health
Gain Project which is funded by North Thames (West) Regional Gain Project which is funded by North Thames (West) Regional Health Authority and the Health Education Authority. We thank Paul Valentine (Library Manager, West London Healthcare
NHS Trust) for his help in collecting all of the papers reviewed.

1 Berlin JA, Colditz GA. A meta-analysis of physical activity in the prevention of coronary heart disease. Am $\mathcal{F}$ Epidemiol in the prevention of

2 Allied Dunbar National Fitness Survey. Main findings. London: Sports Council and Health Education Authority, don: Sports

3 Office of Population Censuses and Surveys. Health survey for England 1992. London: HMSO, 1994.

4 Hoyt MF, Janis IL. Increasing adherence to a stressful 
decision via a motivational balance sheet procedure: A field experiment. F Pers Soc Psychol 1975;31:833-9.

5 Reid EL, Morgan RW. Exercise prescription: A clinical trial. Am $\mathcal{F}$ Public Health 1979;69:591-5.

6 King AC, Fredericksen LW. Low-cost strategies for increasing exercise behaviour. Behav Modif 1984;8:3-21.

7 MacKeen PC, Rosenberger JL, Slater JS, Channing Nicholas W, Buskirk ER. A 13 year follow up of a coronary heart disease risk factor screening and exercise programme for 40-59 year old men: Exercise habit maintenance and physiologic status. Fournal of Cardiopulmonary Rehabilitation 1985;5:510-23.

8 Kriska AM, Bayles C, Cauley JA, Laporte RE, Sandler RB, Pambiano G. A randomised exercise trial in older women: increased activity over two years and the factors associated with compliance. Med Sci Sports Exer 1986;18:557-62.

9 King AC, Barr Taylor C, Haskell WL. De Busk RF. Strategies for increasing early adherence to and long term maintenance of home based exercise training in healthy middle aged men and women. Am F Cardiol 1988;61:628-32.

10 Noland MP. The effects of self monitoring and reinforcement on exercise adherence. Research Quarterly for Exercise and Sport 1989;60:216-24.

11 King AC, Haskell WL, Barr Taylor C, Kraemer HC, DeBusk $\mathrm{RF}$. Group Vs home based exercise training in healthy older men and women. f AMA 1991;266:1535-42.

12 Suter E, Marti B. Predictors of exercise adoption and adherence of middle-aged sedentary men in randomised controlled trial. Clinical fournal of Sports Medicine 1992; 2:261-7.

13 Marcus BH, Stanton AL. Evaluation of relapse prevention and reinforcement interventions to promote exercise adand Sport 1993;64:447-52.
14 Astrand R, Rodahl K. Textbook of work physiology. 3rd ed. New York: McGraw-Hill 1986;304

15 King AC, Haskell WL, Young DR, Oka RK, Stefanick ML Long term effects of varying intensities and formats of physical activity on participation rates, fitness and lipoproteins in men and women aged 50-65 years. Circulation 1995;91:2596-604

16 Miller WR, Rollnick S. Motivational interviewing: preparing people to change addictive behaviour. Guildford: The Guildford Press, 1991;3-5.

17 Najavits LM, Weiss RD. Variations in therapist effectiveness in the treatment of patients with substance use disorders: in empirical review. Addition 1994;89:679-88

18 Borg GV, Linderholm $\mathrm{H}$. Perceived exertion and pulse rate during graded exercise in various age groups. Acta Medica during graded exercise in various

19 King AC, Harris RB, Haskell WL. Effect of recruitment strategy on types of subjects entered into a primary prevention clinical trial. Annals of Epidemiology 1994;4:312 20.

20 Dishman RK, Sallis JF. Determinants and interventions for physical activity and exercise. In: Bouchard C, Shephard RJ, Stephens T. Physical activity, fitness and health: international proceedings and consensus statement 1992. Champaign, IL: Human Kinetics Publishers, 1994 214-38.

21 Prochaska JO, DiClimente CC. Stages and processes of self-change in smoking: toward an integrative model of change. f Consult Clin Psychol 1983;5:390-5.

22 Marcus BH, Simkin LR. The stages of exercise behaviour. 7 Sports Med Phys Fitness 1993;33:83-8.

23 Biddle S, Fox K, Edmunds L. Physical activity promotion in primary health care in England. London: Health Education Authority, 1994. 